\title{
Immunopathology of Herpes Simplex Virus Infections
}

M. Z. DOYMAZ and B. T. ROUSE

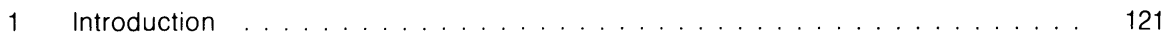

2 T Cell-Mediated IP . . . . . . . . . . . . . . . . . . . . . . . . . . . . 122

$2.1 \mathrm{CD8}^{+} \mathrm{T}$ Cell-Mediated IP . . . . . . . . . . . . . . . . . . . . . . . . . . 122

$2.2 \mathrm{CD}^{+} \mathrm{T}$ Cell-Mediated IP . . . . . . . . . . . . . . . . . . . . . . . . . . . 123

$3 \quad \mathrm{IP}$ in $\mathrm{HSV}$ Infections . . . . . . . . . . . . . . . . . . . . . . . . . . . . . . . 125

3.1 Herpetic Stromal Keratitis . . . . . . . . . . . . . . . . . . . . . . . . . . . . 126

3.1 .1 T Cells in the IP of HSK . . . . . . . . . . . . . . . . . . . . . . . . . . . . . 127

3.1 .2 Mechanism of T Cell-Mediated IP in HSK . . . . . . . . . . . . . . . . . . . . . . 130

3.1.3 The Role of Non-T Cell-Mediated Mechanisms in HSK . . . . . . . . . . . . . . . . . . 132

4 Summary and Prospects ... . . . . . . . . . . . . . . . . . . . . . . . 132

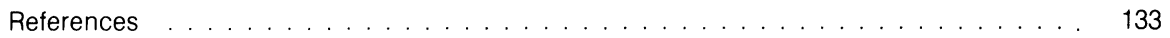

\section{Introduction}

The great majority of accounts of immune mechanisms in virus infections have dealt with protective aspects, but it is evident that immune reactions against infected cells or viral antigens may cause tissue damage. Indeed, it is likely that, during clearance of most if not all viruses, an inflammatory reaction ensues after a T cell response is generated (MIMS 1983). It is perhaps a matter of semantics as to whether or not this should be described as immunopathology (IP). For the purpose of this review, IP will be considered as a chronic inflammatory reaction mediated primarily by the immune system that results in tissue damage or a change in immune function which is initiated and perhaps perpetuated by virus infections. Such situations result more commonly following infections with noncytopathic viruses which persist in an expressed form in the body (SISSONS and BORYSIEWICZ 1985). Although herpes simplex virus (HSV) is persistent, clearly it is not usually expressed, and productive infections are highly cytopathic. Consequently, HSV is unlikely to participate in many immunopathological situations. Before discussing these, our review briefly surveys the state of affairs with other agents which best indicate immunopathological disease mechanisms

Department of Microbiology, College of Veterinary Medicine University of Tennessee, Knoxville, Tennessee 37996-0845, USA 
and which provide clues to understanding those processes that occur in HSVinduced IP.

Immunopathological states result from many circumstances. Most investigations deal with inflammatory reactions which involve lgE, whose reaction with antigens leads to the elaboration and secretion of inflammatory molecules from mast cells. There are few, if any, well studied situations in which IgE antibodies to viral antigens have been recorded and considered to participate in IP. However, reports of IgE antibodies against HSV have occurred (IDA et al. 1983), but their relevance as regards immunity or IP are not resolved. A second well recognized immunopathological mechanism involves the chronic production of immune complexes that become trapped in tissues and trigger inflammatory responses in which complement components and neutrophils play a major role (MEHTA et al. 1977; OLDSTONE et al. 1983). The critical parameter in the mediation of immune complex disease appears to be the chronic production of low affinity nonneutralizing antibody to some product of the virus (MIMS 1983). Thus, the immune response fails to dislodge the virus and the entrapment of complexes in various tissues triggers inflammatory responses. Immune complex disease, at least with viral antigens, has received little recent study and it is unclear if this mechanism accounts for the IP of any HSV infections. However, as discussed subsequently, possible candidates include stromal keratitis and the rare disease erythema multiforme (ROUSE 1985).

\section{T Cell-Mediated IP}

Most current interest in viral-induced IP involves T cell-mediated mechanisms and the prospect that many viruses may in some way trigger autoimmune inflammatory responses which usually involve T cells (TER MEULEN 1989). The latter topic received an excellent review in a recent volume in this series (OLDSTONE 1989). Especially prominent among hypotheses to explain autoimmune reactions triggered by virus infections is that the viruses could share antigens with self-tissues (molecular mimicry). The immune response to these molecular mimics may in some way disrupt the immunoregulatory process which normally prevents autoreactive responses from occurring. Exactly how molecular mimicry on the part of viral antigens leads to autoimmunity is not understood but has been discussed in some detail in the aforementioned volume (FUJINAMI 1989).

\section{1 $\mathrm{CD}^{+}{ }^{+}$T Cell-Mediated IP}

The role of $T$ cells and the likely means by which they contribute to IP in viral infections has received the most study with lymphocytic choriomeningitis (LCM) viral infection of mice (BUCHMEIER et al. 1980). In this disease, a fatal immunopathological disease occurs around 1 week following intracerebral infection of 
immunologically competent mice. The disease is characterized by massive extravasation of lymphocytes and monocytes into the cerebrospinal fluid (CSF) with the inflammatory process involving the leptomeninges, choroid plexus, and ependyma. These sites represent the distribution of infected cells. The key to disease development is the $\mathrm{CD}^{+}{ }^{+}$subset of $\mathrm{T}$ cells which react with limited epitopes on the LCM virus (ALLAN et al. 1987; DIXON et al. 1987). From in vitro studies, a nonapetide appears to be the dominant epitope recognized in one strain of mice and this recognition is effected by a very limited T cell repertoire (WHITTON et al. 1989; KLAVINSKIS et al. 1989; PIRCHER et al. 1987; YANAGI et al. 1990). The in vivo studies clearly indicate an essential role for $\mathrm{CD}^{+}$cells. In fact, the inflammatory exudates contain few if any CD4 ${ }^{+}$cells (DOHERTY et al. 1990). Depleting $\mathrm{CD} 8^{+}$but not $\mathrm{CD} 4^{+}$cells ablates disease and the lesions are only transferable with $\mathrm{CD}^{+}$cells. Indeed, the disease can be induced by intracerebral adoptive transfers of CD8 ${ }^{+}$LCM-specific clones (BEAZINGER et al. 1986). Since $\mathrm{CD} 8^{+}$cells are well known to mediate cytotoxicity in vitro, it could be that the inflammation represents a direct $T$ cell destruction of virus-infected endothelial cells with the subsequent escape of blood elements into the CSF. However, only very few of the $\mathrm{CD} 8^{+}$cells appear to be virus-specific and the frequency of the cytotoxic T lymphocyte (CTL) percursors in the CSF is only of the order of 1 in 2000 (CEREDIG et al. 1989). A more likely mechanism of $\mathrm{CD}^{+}{ }^{+}$-mediated inflammation is the release of various cytokines which recruit and retain both nonspecific CD8 ${ }^{+}$T cells and monocytes (DOHERTY et al. 1990). This delayed-type hypersensitivity (DTH) reaction is more typically the function of $\mathrm{CD} 4^{+}$cells and appears to be the case in HSV infections (ROUSE 1985).

Another model of $\mathrm{CD} 8^{+} \mathrm{T}$ lymphocyte-mediated IP is hepatitis B virus (HBV) infection. This virus is usually not cytotoxic to liver cells and the damage during acute hepatitis is assumed to result from the immune response against the virus (HOLLINGER 1990). Intrahepatic CD8 ${ }^{+} \mathrm{T}$ cells from biopsy specimens of patients and the presence of HBV capsid antigen-specific CTLs in the circulation lend support for the notion that $C D 8^{+}$cells are primary mediators of the IP (MONDELLI et al. 1990). This hypothesis is difficult to prove in the human setting, but it recently received considerable support with the development of a transgenic mouse model (MORIYAMA et al. 1990). In this model, HBV envelope protein (env) expression was accomplished in hepatocytes of transgenic mice. Adoptive transfer of HBV env (amino acids 20-41)-specific $\mathrm{CD}^{+}{ }^{+} \mathrm{T}$ cells into syngeneic transgenic mice induced hepatocyte lysis as assessed by histopathological and liver function assays. In vitro-propagated, monoclonal, $\mathrm{CD}^{+}{ }^{+} \mathrm{T}$ cells were used in adoptive transfer experiments. Thus, these results not only identified the immunopathological T cell subset but also the epitope recognized by the cells.

\section{$2.2 \mathrm{CD}^{+} \mathrm{T}$ Cell-Mediated IP}

In addition to participating in effector aspects of immunity, $\mathrm{CD} 4^{+}$cells play an essential role in regulating the immune response (BRAAKMAN et al. 1987). Immunopathological situations can result either from a sustained reaction of $\mathrm{CD} 4^{+}$ 
antigen-specific cells against infected targets or from the indirect effect of virus infection on $\mathrm{CD}^{+}{ }^{+}$cells themselves. This causes changes in their production of the many cytokines which serve to regulate immunity. There is a growing awareness that this latter mechanism may be an important cause of disease (MIYAJIMA et al. 1988), although viral effects on macrophage and B cell function may be an even more common cause of immune dyscrasia (MORAHAN et al. 1985). For instance, some lesions noted in the Epstein-Barr herpesvirus (EBV) infection are associated with polyclonal activation of $B$ lymphocytes which produce antibodies, including autoantibodies, which in turn can mediate an inflammatory response (RICKINSON et al. 1985). Although HSV can replicate in macrophages, no cytokine-mediated dyscrasia has been reported to result from such interactions.

The reaction of $\mathrm{CD} 4^{+}$effector cells with virus-infected targets usually gives rise to a DTH reaction. Thus CD4 ${ }^{+}$effector cells, although they can be cytotoxic (BRAAKMAN et al. 1987), more usually mediate effector function by the secretion of cytokines, which serve to recruit and change the physiological state of other cell types. This normally protective response is not judged as immur,opathological unless prolonged, occurs in some critical location, or sets off some chronic, tissue damaging, autoreactive response. One of the better studied situations in which the CD4 ${ }^{+}$response is judged to be immunopathological is infection with Theiler's murine encephalitis virus (TMEV), a picornavirus (CLATCH et al. 1985). This natural pathogen of mice causes an enteric infection and occasionally paralysis. Some strains cause a biphasic disease of the central nervous system when injected intracranially (LIPTON 1975). The early disease appears to result from direct effects of the virus on motor neurons in the spinal cord. The later disease has been used as a model for multiple sclerosis since it results in an inflammatory demyelinating lesion that is confined to the white matter (RODRIGUEZ et al. 1986). This is thought to result from virus persisting in oligodendroglia cells combined with a $\mathrm{CD} 4^{+}$-mediated $\mathrm{T}$ cell response against them (CLATCH et al. 1986). Depletion of $\mathrm{CD}^{+}$cells prior to the demyelinating stage results in reduced incidence and disease severity. Thus, the disease appears to be mediated by CD4 ${ }^{+}$T cells (WELSH et al. 1987). Contradicting these results, RODRIGUEZ and SRIRAM (1988), using the same T subset depletion approach, reported that $\mathrm{CD}^{+}{ }^{+} \mathrm{T}$ cells were the primary mediators of demyelination in TMEV-infected mice. Thus, it is possible that $\mathrm{CD}^{+}{ }^{+} \mathrm{T}$ cell involvement in the $\mathrm{IP}$ is not direct but may proceed by providing help to $\mathrm{CD}^{+} \mathrm{T}^{+}$cells. Similar autoreactive, presumably $\mathrm{CD}^{+}{ }^{+}$-mediated, responses occur in coronavirusinduced demyelination in both mice and rats (SORENSON et al. 1980; OUBINE et al. 1988). In such animals, lymphocytes react with myelin basic protein, and cells can transfer the disease in both its clinical and pathological expression to naive animals (WATANABE et al. 1983). Contributing to the pathology in these instances could be the induction of class II antigen expression on nerve cells, which occurs because of the release of interferon- $\gamma\left(\right.$ IFN- $\gamma$ ) by CD4 ${ }^{+}$lymphocytes (MASSA et al. 1986). Such class II-positive cells might act as presenters of autoantigens to induce an autoreactive myelin basic protein-specific response. 
It is clearly evident from the work of MOSSMAN and others that CD4 ${ }^{+}$Iymphocytes in both mice and humans are divisible into at least two principal functional subgroups based upon their cytokine secretion patterns (MOSSMANN and COFFMAN 1989). The two subsets, Th1, comprised of cells that secrete interleukin2 (IL-2) and IFN- $\gamma$ and Th2, comprised of cells that secrete IL-4 and IL-5, play differing roles in immune regulation and presumably in immunity. The best evidence for the varying role of Th1 and Th2 lymphocytes in immunity comes from studies of parasite resistance in mice. In mice strains in which the response in dominated by Th1 cells, animals are protected from infection, but if the Th2 cell response predominates, animals develop lesions that are considered immunopathological (LIEW 1987). The route of exposure to antigen also affects the balance of the response, with intravenous and subcutaneous exposure favoring a Th1 and Th2 response, respectively (LIEW et al. 1985). Factors which influence Th1 or Th2 induction remain ill-defined but may reflect antigen presentation differences, the relative abundance of $T$ cells of unique repertoire, and other regulatory influences on the Th1: Th2 ratio. It does appear as if differing antigenic epitopes can trigger one or the other subset. Thus, an octamer from protein p183 of Leishmania major is a preferential inducer of Th2 in BALB/C mice and immunization with this peptide leads to a heightened susceptibility to disease (LIEW et al. 1990). It is becoming evident that the different cytokines produced by Th1 and Th2 might not only influence the outcome of infection, but cytokines from one subset may influence the function of the other. Currently, there is much interest in the observation that IL-10, produced by Th2 cells in vitro, has a down-regulatory effect on Th1 cells (FIORENTINO et al. 1989). In this regard, IL-10 acts as an antigen-nonspecific suppressor factor.

Although the correlation between Th1 and protection and Th2 and IP appears to hold true in certain parasitic infections, it is uncertain exactly how these effects are carried out. More than likely, however, Th2 cytokines, such as $\mathrm{IL}-4$, which is a potent modulator of the IgE response, are mechanistically involved (PLAUT 1990). The IgE could, in turn, mediate a Jones-Mote-type hypersensitivity reaction.

\section{IP in HSV Infections}

It is characteristic of HSV that, after infection, virus multiplies locally, reaches peak titers between the second and sixth days, and usually becomes undetectable after the tenth day. The local reaction is accompanied by an inflammatory response which, at least in the initial phases, probably represents a reaction to the cells killed by virus replication. The later phases of the inflammatory response are likely to be in part immune-mediated, since $T$ cell reactions can be detectable as early as 4 days after primary infection. During recrudescent infections, when 
T cells can be restimulated in 2-3 days from their memory precursors, the inflammatory response may be largely immune-mediated. If the T cell immune system is functioning normally, clearance of virus rapidly occurs and extensive or prolonged tissue injury does not result from the $T$ cell antiviral response. Accordingly, the state of affairs is usually not considered as immunopathological. However, if: (a) inflammatory responses occurring in certain locations are prolonged; (b) the regenerative capacity of cells is destroyed or limited, or (c) the repair deposits material that impairs the function of some organs, then the situation can be considered as immunopathological. Herpetic infections of the eye best illustrate this scenario, e.g., herpetic stromal keratitis (HSK), which as discussed below appears to largely represent an immunopathological response to HSV in the cornea.

Uveitis is a second HSV-induced ocular lesion that may have an immunopathological explanation. This is a very rare syndrome in humans, but a rabbit animal model has been established to study its pathogenesis $(\mathrm{OH} 1976)$. Animals are infected via the cornea or anterior chamber and those animals with lesions in the uveal tract are given a second intravitreal infection of virus. The prolonged inflammatory response which follows is considered, at least in part, immunopathological $(\mathrm{OH}$ et al. 1985). Accordingly, the lesion can also be induced with replication incompetent virus and efforts to recover infectious virus from the inflammed uvea are usually unsuccessful $(\mathrm{OH}$ 1976). The actual mechanism of the IP has not been fully investigated. Conceivably the virus could set off an autoimmune reaction to some component in the uveal tract. A similar situation may be occurring in human uveitis. Thus, uveitis can be established by immunizing animals against as $S$ antigen isolated from the retina (RAO et al. 1989), and uveitis patients respond to management with corticosteroids (DINNING 1984).

\subsection{Herpetic Stromal Keratitis}

Herpetic infections of the cornea are the leading nontraumatic cause of blindness in the United States and there are an estimated 500000 individuals who suffer from herpetic eye disease (HYNDIUK and GLASSER 1986). Although acute infections of the corneal surface are well controlled by antivirals, especially acycloguanosine, the corneal stroma may also become involved, particularly as a result of recurring infections associated with reactivation from latency (O'BRIEN 1986). This inflammatory disease in the stroma often leads to corneal scarring and neovascularization, permanent endothelial destruction with corneal edema, and even secondary glaucoma and cataract (KAUFMAN 1978). One reason for suspecting that the stromal manifestations represent an immunopathological disease is that they respond well to corticosteroid immunosuppression (KAUFMAN 1978). There is a strong, yet still unproven, suspicion that HSK represents an inflammatory immunogenic response to intrastromal viral antigens (METCALF and KAUFMAN 1976). Epithelial keratitis, on the other hand, which occurs both as a primary and a recurring infection, is a mainfestation of viral-induced cytolysis of the superficial epithelium and responds well to antivirals (DANIELS 
1982). In this form of herpetic corneal disease, the use of corticosteroids leads to further ocular damage. In humans there are two principal expressions of HSK - a nonnecrotizing (disciform keratitis) and a necrotizing variety. In both instances neither the role of replicating HSV nor the part played by the immune response in contributing to the lesion is understood. It is also unclear what determines the pattern of recovery and resolution.

Most of our mechanistic understanding of the pathogenesis of HSK comes from studies in rabbit and mouse models (METCALF et al. 1976; O'BRIEN 1984; OPREMCAK et al. 1990). Of the two, the rabbit is the most convenient to model the histopathology and investigate the effects of treatment, but it is the mouse model which permits a better understanding of the role of the immune response in contributing to the tissue damage. In the rabbit, the disease usually takes the necrotizing form and in this expression polymorphonuclear neutrophils (PMNs) dominate the inflammatory responses (MEYERS-ELLIOT and CHITJIAN 1981). Indeed, the severity of the disease is markedly suppressed if PMNs are depleted or complement activity is inhibited (MEYERS-ELLIOT and CHITJIAN 1981). Consequently, the mechanism of pathology may be a combination of direct viral damage perhaps combined with immune complex-mediated IP (ROUSE 1985). However, the issue has not been resolved and the rabbit is not a convenient model to resolve immunological controversies, particularly if $\mathrm{T}$ cells are involved.

Fortunately, mice can also be experimentally infected with certain strains of HSV and develop HSK; however, abrasion of the cornea before infection is usually required and only some strains of mice are susceptible (STULTING et al. 1985). Thus, the C57/BL and C3H strains are resistant, whereas HSK can readily be induced in BALB/C and A/J mice. Murine HSK is a model of disciform nonnecrotizing keratitis and in this form the inflammation is dominated, after an initial stage, by lymphocytes and other mononuclear cells or by PMNs, depending upon the viral strain used (HENRICKS and TUMPEY 1990; OPPEMCAK et al. 1990). Replicating virus, or viral antigens, are difficult to demonstrate. It is the murine model which we and others have used in an attempt to better understand the IP of HSK (METCALF et al. 1979; RUSSELL et al. 1984). The aim has been to establish the immune processes which contribute to the tissue damage and hopefully to identify the target viral antigens and the role of viral replication in the disease expression. The mouse is not an ideal model to simulate human HSK since the latter usually results from repeated recurrent infections. HSK is usually a progressive disease in mice and spontaneous recurrences from latent infection do not occur. When such recurrences are induced experimentally by procedures such as iontophoresis the mice do not clinically express the disease (O'BRIEN 1984).

\subsubsection{T Cells in the IP of HSK}

Early histopathological studies of HSK by METCALF and HELMSEN (1977) led to the suspicion that HSK represents an immunopathological reaction. Thus, mononuclear inflammatory cells late in the disease were found in close contact with keratinocytes, which themselves appeared to be undergoing degenerative changes. The lesions were interpreted to represent $T$ cell-mediated attacks on 
infected cells. Support for this idea was later dramatically presented by METCALF et al. (1979) when they demonstrated that HSK lesions fail to occur in athymic mice. Such mice, however, developed severe corneal epithelial infections and virus disseminated beyond the ocular site of infection which included the brain. Mice ultimately developed encephalomyelitis.

RUSSELL et al. (1984) confirmed METCALF'S findings and extended them using reconstitution experiments. Thus, athymic mice given adoptive transfers of HSV immune cells rapidly developed a severe form of HSK. The peak reaction occurred earlier in athymic mice that received adoptive transfers of immune cells than following primary infection of euthymic mice. The cells transferring the keratitis were identified as T cells, but their subset nature or function was not definitively characterized. On the basis of these indirect approaches it was concluded that CTLs were principally involved. To understand the mechanisms of IP, METCALF (1984) compared the IP-restorative capacity of lymphocytes taken from mice previously infected either subcutaneously or intraperitoneally with HSV. The former population was found to be more effective, but the reasons were not elucidated. We now know, however, that populations from subcutaneously immunized mice would have far greater DTH mediating activity than populations from mice immunized intra-peritoneally (NASH and GELL 1983). This may argue a role for the involvement of DTH.

Most groups working on the murine HSK model seem to agree that the lesion largely represents $T$ cell-mediated IP, but the actual mechanism remains uncertain. Basically, there are two schools of thought. Either the lesion primarily represents a $\mathrm{CD} 8^{+}$-mediated immunopathological response, with in vivo cytotoxicity playing a principal part, or the lesion represents a $\mathrm{CD} 4^{+}$-mediated one. In this instance, the $\mathrm{CD}^{+}{ }^{+}$cells are assumed to release various cytokines, including destructive ones such as tumor necrosis factor, or they themselves mediate cytotoxicity.

A primary role for $\mathrm{CD}^{+}$CTLs has been advanced by the observations of HENDRICKS and colleagues (1989a,b). They took advantage of the peculiar phenomenon in the eye that, following injection of an antigen into the anterior chamber (AC), animals develop a partial state of immune tolerance which primarily affects aspects of cell-mediated immunity (KAPLAN and STREILEIN 1977; KSANDER and HENDRICKS 1987). Using this model, 20 min after the AC injection, the virus was applied topically to the corneas. The expectation was that the animals would be unable to generate some aspects of cellular immunity and consequently would not develop HSK in the topically infected eye. This, in fact, was found to be the case. To implicate CD8 ${ }^{+}$CTLs as the probable mediators of HSK, HENDRICKS et al. (1989b) later exploited the observation that certain $\mathrm{gC}$ mutant viruses, when injected into the AC, tolerize mice only for CTLs and not for DTH. Thus, if CTLs were the mediators of IP, then AC injection of the mutant was also expected to ablate HSK following topical infection of wild-type virus. Such results were obtained. This rather indirect argument has not been confirmed by others, and it is curious to note that the usual pattern of events following $A C$ exposure to antigen is reported to be somewhat different. Accordingly, $A C$ injection of virus 
tolerizes mice for DTH but not for CTLs (STREILEIN 1987; IGIETSEME et al. 1989). Thus, it is uncertain why the initial experiments of the HENDRICKS group would not result in HSK, if indeed CTLs were involved, because in that model the CTL response should still be operative.

The notion that $\mathrm{CD} 4^{+} \mathrm{T}$ cells mediate IP in the murine HSK model was advocated by our group and others (NEWELL et al. 1989a, b; HENDRICKS and TUMPEY 1990). Initial evidence was obtained by using monoclonal antibodies specific for T cell subsets to in vivo deplete animals of a particular cell type (NEWELL et al. 1989a). The outcome following corneal infections with the RE strain of HSV to groups of control, $\mathrm{CD} 4^{+}$-depleted, or $\mathrm{CD}^{+}{ }^{\top}$ cell-depleted mice were measured. The results were clear-cut. In the absence of $\mathrm{CD}^{+}{ }^{+} \mathrm{T}$ cells, HSK lesions were markedly reduced or inapparent. Interestingly, the elimination of $\mathrm{CD}^{+}{ }^{+} \mathrm{T}$ cells resulted in more severe HSK and spread of virus to the brain to produce encephalomyelitis. Presumably, $\mathrm{CD} 8^{+} \mathrm{T}$ cells subserve a protective role against HSK and do not mediate IP. Recently, HENDRICKS and TUMPEY (1990) have confirmed that $\mathrm{CD} 4^{+} \mathrm{T}$ cells mediate IP in HSK, but only in the same RE HSV strain as was used in our study. Interestingly, they found that IP was mediated by CD $8^{+}$ T cells if the KOS strain of HSV was used as challenge virus. Furthermore, the nature of stromal inflammation induced by the RE strain of HSV-1 seems somewhat different from HSK induced by KOS HSV-1 (HENDRICKS, personal communication). Accordingly, in RE strain-induced inflammation, the migration of Langerhans' cells to the central cornea is more prominent and the inflammation is characterized as neutrophilic, whereas in KOS-induced HSK mononuclear cells are prominent. Presently, no adequate explanation has been put forward as to why the strain of the virus induces markedly different disease patterns Antigen differences between the viral strains could provide the answer to this question.

To further resolve the part played by $\mathrm{CD} 4^{+}$and $\mathrm{CD} 8^{+} \mathrm{T}$ cells in $\mathrm{HSK} \mathrm{IP}$, we have established an experimental model in which thymectomized and $T$ celldepleted $(T(-))$ mice were reconstituted with different numbers and types of $T$ cells from immune or naive mice (DOYMAZ and ROUSE 1991). Thymectomy combined with the administration of anti-CD4 and anti-CD8 sera provided a model animal that failed to develop HSK corneal challenge. Donor cells for adoptive transfer were taken from normal Balb/c mice undergoing HSK. Accordingly, retropharyngeal and cervical lymph node cells were stimulated in vitro with HSV for 4 days then negatively depleted in vitro of $\mathrm{CD}^{+}$or $\mathrm{CD}^{+}$prior to transfer to $T(-)$ mice which had been infected on the cornea with HSV 2 days previously. We observed that HSK occurred only in recipients of unfractionated and CD8 ${ }^{+}$. depleted populations but not in recipients of the $\mathrm{CD} 4^{+}$-depleted population. Moreover, if sufficient cells were transferred $\left(2 \times 10^{7}\right.$ or higher) a disease comparable in severity to that observed in the direct HSK model occurred. Naive T lymphocytes, irrespective of the surface phenotype, were unable to induce HSK upon transfer to $\mathrm{T}(-)$ mice. Taken together, our results provide further evidence that $\mathrm{CD} 4^{+}$but not $\mathrm{CD} 8^{+} \mathrm{T}$ cells were mediating the IP in HSK, a notion recently confirmed by others (HENDRICKS and TUMPEY 1990). 


\subsubsection{Mechanism of T Cell-Mediated IP in HSK}

Although there is reasonable agreement that $T$ cells of some type are involved in mediating IP in HSK, how this occurs is far from clear. Indeed since a particular $T$ cell subset can subserve several different effector mechanisms, the studies related to these questions are more difficult and the answers may not be clear-cut (DOHERTY et al.1990). Added uncertainties in the case of HSK come from the fact that assays measuring the functions of T cells in HSV mice models usually require in vitro stimulation steps, increasing the possibility of introduction of artifacts. Furthermore, the microanatomy of corneal tissues makes in situ analysis of the function of T cells almost impossible (STREILEIN 1987). Thus, T cells obtained from local lymph nodes (retropharyngeal and cervical) seem to be the best candidate population to study. Since, in vivo depletion and adoptive transfer experiments indicated that $\mathrm{CD} 4^{+} \mathrm{T}$ cells were crucially involved in HSK $I P$, we concentrated our efforts on the function of these cells.

One of the more universally accepted functions of $\mathrm{CD}^{+} \mathrm{T}$ cells is the mediation of DTH reactions. This notion has laso been clearly demonstrated for HSV in mice (NASH et al. 1981; ROUSE 1985). Furthermore, we have data indicating that, both in normal or reconstituted mice experiencing HSK, a significant DTH response is mounted against HSV antigens. Histopathological examination of diseased corneas shows that inflammatory cell infiltrates are reminiscent of conventional DTH reactions. Another approach to assess the role of DTH in immune responses is to determine the lymphokine secretion patterns of CD4 ${ }^{+}$ cells (MOSSMANN and COFFMAN 1989). One expects that cytokines such as IL-2 and IFN- $\gamma$ would be involved and that modulating the levels of such cytokines would influence the outcome of HSK. That this is indeed the case has been noted recently by HENRICKS (personal communication) and in our own studies (DOYMAZ and ROUSE, unpublished).

Direct cytotoxicity on virally infected corneal cells is another mechanism by which $\mathrm{CD}^{+}{ }^{+}$cells might participate in HSK IP. This type of CTL predominates in human HSV infections (SCHMID 1988; YASUKAWA et al. 1988). Moreover, keratinocytes readily express $\mathrm{MHC}$ class II molecules upon stimulation by IFN- $\gamma$ and can present HSV antigens to autologous CD4 ${ }^{+}$T cells (CUNNINGHAM and NOBLE 1989). The elements required for $\mathrm{CD} 4^{+} \mathrm{CTL}$ recognition, such as $\mathrm{CD} 4^{+} \mathrm{T}$ cells themselves and class II-expressing antigen-presenting cells, are found in murine eyes with HSK (MCBRIDE et al.1988; DOYMAZ et al.1991). Furthermore, we have recently documented that murine $\mathrm{CD} 4^{+}$cells may express HSV-specific class II-restricted cytotoxicity (KoLAITIS et al. 1990). Similar CD4 ${ }^{+}$cytotoxic cells can be demonstrated in draining retropharyngeal and cervical lymph nodes of mice experiencing HSK (Table 1). These cells specifically lysed syngeneic target cells infected with HSV. Moreover $\mathrm{I}^{+}{ }^{+}$syngeneic target cell lysis was still intact in $\mathrm{CD}^{+}{ }^{+}$cell-depleted mice (DOYMAZ et al. 1991). These findings were particularly interesting in the context of HSK IP, since mice lacking CD8 ${ }^{+}$lymphocytes experience a more pronounced stromal disease than do normal animals (NEWELL et al. 1989a). We also demonstrated the presence of $\mathrm{CD}^{+}{ }^{+} \mathrm{T}_{\text {lymphocytes and }}$ 


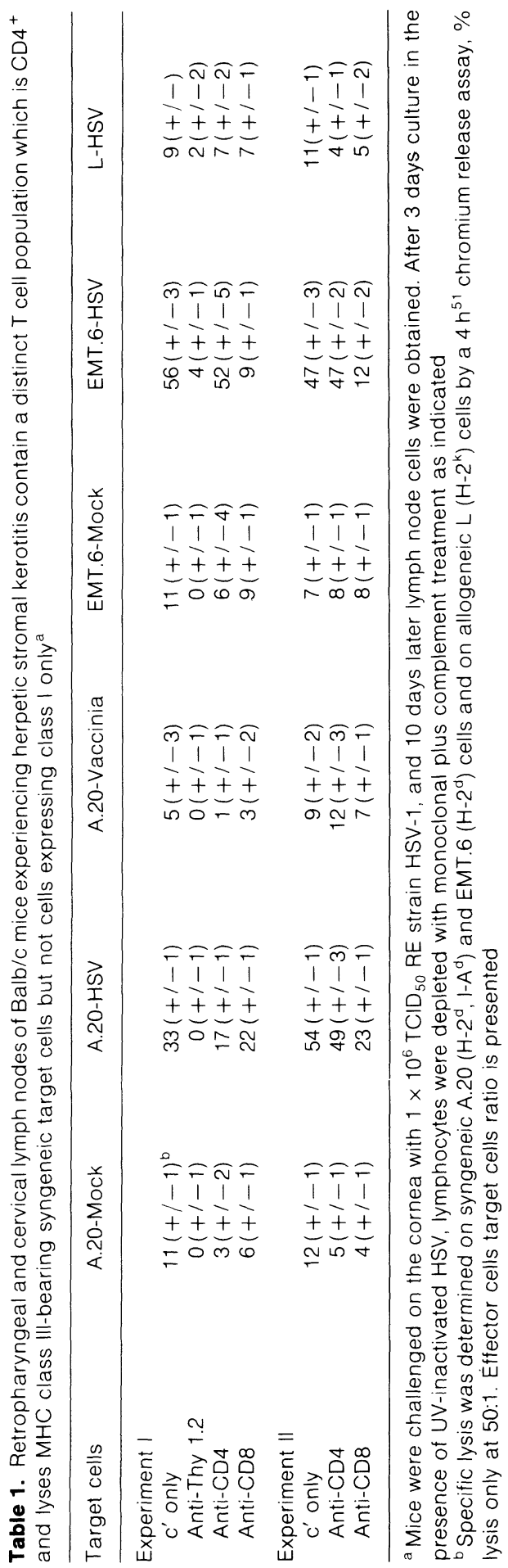


MHC II-expressing potential antigen-presenting cells in the corneal stroma during the clinical phase of the disease (DOYMAZ et al. 1991). It will be important to determine if $\mathrm{CD}^{+}{ }^{+}$class $\|$-restricted CTLs are present in corneal tissues and the cytokine secretion profile of such cells.

\subsubsection{The Role of Non-T Cell-Mediated Mechanisms in HSK}

It remains probable that the IP of clinical HSK is not confined to T cell mechanisms. Indeed, FOSTER and colleagues (1986) have indicated a possible role for humoral immune-mediated pathology. Thus, in studies of disease patterns in immunoglobulin heavy chain gene $(\mathrm{IgH})$ congenic mice strains, susceptibility to HSK was correlated with the $\mathrm{IgH}$ phenotype. Such studies indicate that the immunoglobulin repertoire may in some way influence susceptibility to HSK but how this occurs remains ill-defined. It is possible that the type of antibody response made by susceptible strains renders them more likely to generate inflammatory immune complexes. Indeed, in the rabbit model of HSK, the disease pattern may be consistent with immune complex-mediated IP (RouSE 1985). Thus, in sucin animals PMNs are prominently involved in the inflammatory response (MEYERS-ELLIOT and CHITIAN 1981) and plasma cells can be found in the limbus and corneal tissues in some instances (METCALF et al. 1976; MEYERS-ELLIOT and CHITJIAN 1981). Moreover, polyclonal anti-PMN antibody treatment or complement depletion of rabbits significantly reduced the severity of the disease (MEYERS-ELLIOT and CHITJIAN 1981). In the rabbit model, it is difficult to assess any additional role of $T$ cells. Morever, it is also possible that the anti-PMN serum used for depletion lacked strict specificity and was inhibitory to T cells. Accordingly, the diminished HSK and reduction in anti-HSV antibody observed could have resulted from effects on helper T cells (MEYERS-ELLIOT and CHITJIAN 1981).

\section{Summary and Prospects}

There is good agreement that HSK, in both its natural setting and in animal models, represents an immunopathological response to HSV. We do not know the nature of target antigens or how and in which cells they are expressed, nor indeed are we certain about the actual mechanism(s) involved in IP. With the recent availability of new animal model systems, along with an ever increasing spectrum of antisera that can ablate various cell types, T cell receptor expression, and levels of cytokines in vivo, rapid progress in further defining the mechanisms of IP in HSK is to be anticipated. Hopefully, the outcome of such studies will be the development of new treatment or prevention strategies for this tragic disease. 


\section{References}

Allan JE, Dixon JE, Doherty PC (1987) Nature of inflammatory process in the central nervous system of mice infected with lymphocytic choriomeningitis virus. In: Oldstone MB (ed) Arenaviruses. Biology and immunotherapy. Springer, Berlin Heidelberg New York, pp 131-143 (Current topics in microbiology and immunology, vol 134)

Beazinger J, Hengartner H, Zinkernagel RM (1986) Cloned cytotoxic T cells specific for lymphocytic choriomeningitis virus induce acute disease and primary footpad swelling in infected mice. Med Microbiol Immunol (Berl) 175: 201

Braakman E, Rottevell FTM, van Bleek G, van Seventer GA, Lucas CJ (1987) Are MHC Class-II restricted cytotoxic T lymphocytes important. Immunol Today 8: 265-267

Buchmeier MJ, Welsh RM, Dutko FJ, Oldstone MBA (1980) The virology and immunobiology of lymphocytic choriomeningitis virus infection. Adv Immunol 30: 275-331

Ceredig R, Allan JE, Tabi Z, Lynch F, Doherty PC (1989) Phenotypic analysis of the inflammatory exudate in murine lymphocytic choriomeningitis. J. Exp Med 165: 1539-1551

Clatch RJ, Melvold RW, Miller SD, Lipton HL (1985) Theiler's murine encephalomyelitis virus (TMEV) induced demyelinating disease in mice is influenced by the $\mathrm{H}-2 \mathrm{D}$ region. Correlation with TMEV specific delayed type hypersensitivity reactions. J Immunol 135: 1408-1414

Clatch RJ, Lipton HL, Miller SD (1986) Characterization of Theiler's murine encephalomyelitis virus (TMEV) specific delayed type hypersensitivity responses in TMEV-induced demyelinating disease: correlation with clinical signs. J Immunol 136: 920-927

Cunningham AL, Nobel JR (1989) Role of keratinocytes in human recurrent herpetic lesions. Ability to present herpes simplex virus antigen and act as targets for T lymphocyte cytotoxicity in vitro. $J$ Clin invest 83: 490-496

Daniels CA (1982) Viral and rickettsial infections. In: Gardner A, Klintworth GK (eds) Pathobiology of ocular diseases. A dynamic approach. Dekker, New York, pp 249-266

Dinning WJ (1984) The therapy of uveitis. A review. In: Saari KM (ed) Uveitis updated. Excerpta Medica, New York, pp 477-481

Dixon JE, Allan JE, Doherty PC (1987) The acute inflammatory process in murine lymphocytic choriomeningitis virus is dependent on Ly $2^{+}$immune T cells. Cell Immunol 107: 8-14

Doherty PC, Allan JE, Lynch F, Ceredig R (1990) Dissection of an inflammatory process induced by $\mathrm{CD}^{+} \mathrm{T}$ cells. Immunol Today 11: 55-59

Doymaz MZ, Rouse BT (1991) Herpetic stromal keratitis: an immunopathological disease mediated by $\mathrm{CD}^{+}{ }^{+} \mathrm{T}$ lymphocytes (to be published)

Doymaz MZ, Mercadal CM, Destephano D, Rouse BT (1991) MHC-II restricted, CD4 ${ }^{+}$cytotoxic T lymphocytes (CTL) specific for herpes simplex virus-1: implications for the development of herpetic stromal keratitis (HSK) in mice (to be published)

Fiorentino DF, Bond BW, Mossmann TR (1989) Two types of mouse T helper cells. IV. T H2 clones secrete a factor that inhibits cytokine production by T HI cells. J Exp Med 170: 2081-2095

Foster CS, Tsai Y, Monroe JG, Campbell R, Cestari M, Wetzig R, Knipe D, Greene MI (1986) Genetic studies on murine susceptibility to herpes simplex keratitis. Clin Immunol Immunopathol 40: $313-325$

Fujinami RS (1989) Immune responses against myelin basic protein and/or galactocerebroside cross-react with viruses: implications for demyelinating disease. In: Oldstone MB (ed) Molecular mimicry. Cross-reactivity between microbes and host proteins as a cause of auto immunity. Springer, Berlin Heidelberg New York, pp 93-100 (Current topics in microbiology and immunology, vol 145)

Hendricks RL, Tumpey T (1990) Contribution of virus and immune factors to herpes simplex virus type 1 induced corneal pathology. Invest Opthalmol Vis Sci 31: 1929-1939

Hendricks RL, Epstein RJ, Tumpey T (1989a) The effects of cellular immune tolerance to HSV-1 antigens on the immunopathology of HSV-1 keratitis. Invest Opthalmol Vis Sci 30: 105-115

Hendricks RL, Tao MSP, Glorioso JC (1989b) Alterations in the antigenic structure of two major HSV-1 glycoproteins, $\mathrm{gC}$ and $\mathrm{gB}$, influence immune regulation and susceptibility to murine herpes keratitis. J Immunol 142: 263-269

Hollinger FB (1990) Hepatitis B virus. In: Fields BN, Knipe DM (eds) Virology, 2nd edn. Raven, New York, pp 2171-2224

Hyndiuk RA, Glasser DB (1986) Herpes simplex keratitis. In: Tabbarra K, Hyndiuk RA (eds) Infections of the eye. Diagnosis and management. Little Brown, Boston, pp 343-368 
Ida S, Siragenian RP, Notkins AL (1983) Cell bound and circulating IgE antibody to herpes simplex virus. J Gen Virol 64: 533-537

Igietseme JV, Calzada PJ, Gonzalez AR, Streilein, Atherton SS (1989) Protection of mice from herpes simplex virus-induced retinitis by in vitro activated immune cells. J Virol 63: 4808-4813

Kaplan HJ, Streilein JW (1977) Immune response to immunization via the anterior chamber of the eye. I. F1 lymphocyte induced immune deviation. J Immunol 118: 809-814

Kaufman HE (1978) Herpetic keratitis. Invest Opthalmol Vis Sci 117: 941-957

Klavinskis LS, Lindsay-Whitton J, Oldstone MBA (1989) Molecularly engineered vaccine which express an immunodominant $T$ cell epitope induces cytotoxic $T$ lymphocytes that confer protection from lethal virus infection. J Virol 63: 4311-4316

Kolaitis G, Doymaz M, Rouse BT (1990) Demonstration of MHC class II restricted cytotoxic T lymphocytes in mice against herpes simplex virus. Immunology 71: 101-106

Ksander BR, Hendricks RL (1987) Cell-mediated immune tolerance to HSV-1 antigens associated with reduced susceptibility to HSV-1 corneal lesions. Invest Ophthalmol Vis Sci 28: 1986-1992

Liew FY (1987) Analysis of host protective and disease promoting T cells. Ann Inst Pasteur Immunol 138: 749-755

Liew FY, Hale C, Howard JG (1985) Prophylactic immunization against experimental Leishmaniasis. IV subcutaneous immunization prevents the induction of protective immunity against fatal Leishmania major infection. J Immunol 135: 2095-2101

Liew FY, Millott SM, Schmidt JA (1990) A repetitive peptide of leishmania can activate T helper type 2 cells and enhance disease progression. J Exp Med 172: 1359-1365

Lipton HL (1975) Theiler's virus infection in mice: an unusual biphasic disease process leading to demyelination. Infect Immun 11: 1147-1155

Massq PT, Dorries R, Ter Muelen V (1986) Viral particles induce la expression on astrocytes. Nature 320: $543-546$

McBride BW, McGill JI, Smith JL (1988) MHC-class-I and class-II antigen expression in normal human corneas and in corneas from cases of herpetic keratitis. Immunology 65: 583-587

Mehta PD, Kane A, Thormar H (1977) Quantitation of measles virus-specific immunoglobulins in serum, CSF and brain extract from patients with subacute sclerosing panencephalitis. J Immunol 118: 2254-2261

Metcalf JF (1984) Herpetic keratitis in normal and athymic mice. In: Tabbarra K, Cello RM (eds) Animal models of ocular diseases. Thomas, Spring field, $p p$ 53-62

Metcalf JF, Helmsen R (1977) Immunoelectron microscopic localization of herpes simplex virus antigens in rabbit cornea with anti-human IgG-antiferrin hybrid antibodies. Invest Ophthalmol Vis Sci 9: 779-786

Metcalf JF, Kaufman HE (1976) Herpetic stromal keratitis: evidence for cell-mediated immunopathogenesis. Am Ophthalmol 82: 827-837

Metcalf JF, McNeil JI, Kaufman HE (1976) Experimental disciform edema and necrotizing keratitis in rabbit. Invest Ophthalmol Vis Sci 12: 979-985

Metcalf JF, Hamilton DS, Reichert RW (1979) Herpetic keratitis in athymic (nude) mice. Infect Immun 26: $1164-1171$

Meyers-Elliot RH, Chitjian PA (1981) Immunopathogenesis of corneal inflammation in herpes simplex virus stromal keratitis: role of the polymorphonuclear leucocytes. Invest Ophthalmol Vis Sci 20: $784-798$

Mims CA (1983) Immunopathology in virus diseases. Philos Trans R Soc Lond 308: 18-198

Miyajima A, Miyataka S, Schreurs J, DeVries J, Arai N, Yokota T, Arai K (1988) Coordinate regulation of immune and inflammatory responses by $T$ cell derived lymphokines. FASEB J 2: 24622473

Mondelli MV, Chisari FV, Ferrari C (1990) The cellular immune response to nucleocapsid antigens in hepatitis virus infections. Springer Semin Immunopathol 12: 25-31

Morahan PS, Connor JR, Leary KR (1985) Viruses and versatile macrophage. Br Med Bull 41: 15-21

Moriyama T, Guilhot S, Klopchin K, Moss B, Pinkert CA, Palmiter RD, Brinster RI, Kanagawa O, Chisari FV (1990) Immunobiology and pathogenesis of hepatocellular injury in hepatitis B virus transgenic mice. Science 248: 361-364

Mossmann TR, Coffman RL (1989) Heterogeneity and cytokine secretion patterns and functions of helper T cells. Adv Immunol 46: 111-147

Nash AA, Gell PGH (1983) Membrane phenotype or murine effector and suppressor T cells involved in delayed type hypersensitivity and protective immunity to herpes simplex virus. Cell Immunol 75: $348-355$ 
Nash AA, Gell PGH, Wildy P (1981) Tolerance and immunity in mice infected with herpes simplex virus. Simultaneous induction of protective immunity and tolerance to delayed-type hypersensitivity. Immunology 43: 153-159

Newell CK, Martin S, Sendele D, Mercadal CM, Rouse BT (1989a) Herpes simplex virus-induced stromal keratitis: role of T-lymphocytes subsets in immunopathology. J Virol 63: 769-775

Newell CK, Sendele D, Rouse BT (1989b) Effects of CD4 ${ }^{+}$and CD8 ${ }^{+}$T lymphocyte depletion on the induction and expression of herpes simplex stromal keratitis. Regul Immunol 2: 366-369

O'Brien WJ (1984) Herpetic eye diseases in animals as models for therapeutic studies of acute and latent herpesvirus infections. In: Rapp F, Herpesvirus. Liss, New York, pp 101-120

O'Brien WJ (1986) Antiviral agents. In: Tabbarra K, Hyndiuk R (eds) Infections of the eye. Little Brown, Boston, pp 257-274

Oh JO (1976) Primary and secondary herpes simplex uveitis in rabbits. Surv Ophthalmol 21: 178-182

Oh JO, Minasi P, Grabner G, Ohashi Y (1985) Suppression of secondary herpes simplex uvetis by cyclosporine. Invest Ophthalmol Vis Sci 26: 494-500

Oldstone MBA (1989) Moleculear mimicry as a mechanism for the cause and as a probe uncovering etiological agent(s) of autoimmune disease. In: Oldstone MB (ed) Molecular mimicry. Crossreactivity between microbes and host proteins as a cause of autoimmunity. Springer, Berlin Heidelberg New York, pp 127-135 (Current topics in microbiology and immunology, Vol 145)

Oldstone MBA, Tishon A, Buchmeier MJ (1983) Virus induced immune complex disease: genetic control of Clq binding complexes in the circulation of mice persistently infected with lymphocytic choriomeningitis virus. J Immunol 130: 912-918

Opremcak EM, Rice BA, Wells PA, Foster CS (1990) Histology and immunohistology of Igh-1 restricted herpes simplex keratitis in Balb/c congenic mice. Invest Ophthalmol Vis Sci 31: 305-312

Oubina JR, Carballal G, Laguens RP, Quintans C, Merani S, Weisshenbacher MC (1988) Mortality induced by adoptive immunity in Junin virus-infected athymic mice Intervirology 29: 61-67

Pircher $\mathrm{H}$, Michalopoulos EE, Iwamato A, Ohashi PS, Beazinger J, Hengartner $H$, Zinkernagel RM, Mak T (1987) Molecular analysis of the antigen receptor of virus-specific cytotoxic $T$ cells and identification of a new V-alpha family. Eur J Immunol 17: 1843-1847

Plaut M (1990) Antigen specific lymphokine secretory patterns in atopic diseases. J Immunol 144: 4497-4500

Rao NA, Atalla L, Linker-Israeli M, Chen FY, George IV FW, Martin WJ, Steinman L (1989) Suppression of experimental uveitis in rats by anti-IA antibodies. Invest Ophthalmol Vis Sci 30: 2348-2355

Rickinson AB, Tao QY, Wallace LE (1985) The Epstein-Barr virus as a model of virus-host interactions. Br Med Bull 41: 75-79

Rodriguez M, Sriram S (1988) Successful therapy of Theiler's virus-induced demyelination (DA strain) with monoclonal anti-Ly 2 antibody. J Immunol 140: 2950-2955

Rodriquez M, Pease LR, David CS (1986) Immune-mediated injury of virus-infected oligodendrocytes. Immunol Today 7: 359-363

Rouse BT (1985) Immunopathology of herpesvirus infections. In: Roizman B, Lopez C (eds) Herpesviruses, vol 4. Plenum, New York, pp 103-119

Russell RG, Nasisse MP, Larsen HS, Rouse BT (1984) Role of T lymphocytes in the pathogenesis of herpetic stromal keratitis. Invest Ophthalmol Vis Sci 25: 938-944

Schmid DS (1988) The human MHC-II restricted cellular response to herpes simplex virus type-1 is mediated by $\mathrm{CD}^{+}{ }^{+} \mathrm{CD}^{+} \mathrm{T}$ cells and is restricted to the DR region of $\mathrm{MHC}$ complex. $\mathrm{J}$ Immunol 140: 3610-3616

Sissons JGP, Borysiewiczs LK (1985) Viral immunopathology. Br Med Bull 41: 34-40

Sorenson O, Percy D, Dales S (1980) In vivo and in vitro models of demyelinating diseases. III. JHM virus infection of rats. Arch Neurol 37: 478-484

Streilein JW (1987) Immune regulation and the eye: a dangerous compromise. FASEB J 1: 199-208

Stulting RD, Kindle JC, Nahmias AJ (1985) Patterns of herpes simplex keratitis in inbred mice. Invest Ophthalmol Vis Sci 26: 1360-1367

Ter Meulen V (1989) Virus-induced, cell-mediated autoimmunity. In: Notkins AL, Oldstone MBA (eds) Concepts in Viral pathogenesis III. Springer, Berlin Heidelberg New York, pp 297-303

Watanabe R, Webe H, TerMeulen V (1983) Adoptive transfer of EAE-like lesions by MBP stimulated lymphocytes from rats with corona virus-induced demyelinating encephalomyelitis. Nature 305 : 150-153

Welsh RJC, Tonks P, Nash AA, Blakemore WF (1987) Effects of L3T4 T cell depletion on the pathogenesis of Theiler's murine encephalomyelitis virus infection in CBA mice. J Gen Viral 68: 16591667 
Whitton J, Tishon A, Lewicki H, Gebhard J, Cook T, Salvato M, Joly E, Oldstone MBA (1989) Molecular analysis of a five amino acid cytotoxic $T$ lymphocyte (CTL) epitope: an immunodominant region which induces non-reciprocal CTL crossreactivity. J Virol 63: 4303-4311

Yanagi Y, Maekawa R, Cook T, Kanagawa O, Oldstone MBA (1990) Restricted V segment usage in $T$ cell receptors from cytotoxic $T$ lymphocytes specific for a major epitope of lymphocytic choriomeningitis virus. J Virol 64: 5919

Yasukawa M, Inatsu A, Kobayashi Y (1988) Helper activity in antigen specific antibody production mediated by $\mathrm{CD}^{+}$human cytotoxic $\mathrm{T}$ cell clones directed against herpes simplex virus. J Immunol 140: 3419-3425 